\title{
Opini Masyarakat Kota Medan Terhadap Pemilihan Serentak Presiden Dan Legislatif Tahun 2019
}

\author{
Akhyar Anshori \\ University Muhammadiyah of Sumatera Utara \\ Jalan Mukhtar Basri. No. 3 Medan 20238 \\ e-mail: akhyaransori@umsu.ac.id
}

\begin{abstract}
This study aims to determine the public opinion of the city of Medan against the simultaneous election of the president and legislators in 2019 using quantitative research methods. In determining the sample, the researcher used a probability sampling method, then the sampling technique was a proportional stratified sample. The sample size uses the Slovin formula about determining the number of samples from a particular population with a 5\% error requirement. The subject of this study involved the people of Medan city who have been registered as permanent voters in the upcoming elections in 2019. This study uses correlational analysis of data analysis techniques. Correlational analysis is statistical analysis that seeks to find relationships or influences between two or more variables. The conclusion of this study found that around $95.25 \%$ of respondents knew that the 2019 elections would be held simultaneously while electing the president and legislature. And $77.50 \%$ of respondents agreed to the implementation of presidential and legislative elections carried out simultaneously.
\end{abstract}

Keywords: Public Opinion, Elections, President and Legislature

\begin{abstract}
Abstrak
Penelitian ini bertujuan untuk mengetahui opini masyarakat kota Medan terhadap pemilihan serentak presiden dan anggota legislatif tahun 2019 dengan menggunakan metode penelitian kuantitatif. Pada penentuan sampel, peneliti memakai metode pengambilan sampel secara probability sampling, kemudian teknik penarikan sampelnya berupa sampel berstrata proporsional. Adapun besaran sampel dengan menggunakan rumus Slovin tentang penentuan jumlah sampel dari populasi tertentu dengan syarat kesalahan 5\%. Subjek penelitian ini melibatkan masyarakat kota Medan yang telah terdaftar sebagai pemilih tetap pada Pemilu tahun 2019 yang akan datang. Penelitian ini menggunakan teknik analisis data analisis korelasional. Analisis korelasional adalah analisis statistik yang berusaha untuk mencari hubungan atau pengaruh antara dua buah variabel atau lebih. Simpulan dari penelitian ini menemukan bahwa sekitar 95,25\% responden telah mengetahui bahwa pemilu tahun 2019 akan dilaksanakan secara serentak anatara memilih presiden dan legislatif. Dan $77,50 \%$ responden menyatakan setuju terhadap pelaksanaan pemilihan presiden dan legislatif dilaksasnakan secara bersamaan.
\end{abstract}

\section{Kata Kunci: Opini Publik, Pemilu, Presiden dan Legislatif}


Latar Belakang Masalah

Pemilihan Umum (Pemilu)

2019 bakal digelar secara berbeda.

Yakni Pemilu Legislatif (Pileg) dan

Pemilihan Presiden (Pilpres) akan

dilaksanakan serentak. Berbeda

dengan Pemilu 2014 yang dilakukan

terpisah. Pileg pada 9 April 2014 dan

Pilpres pada 9 Juli 2014. Pasca

Putusan Mahkamah Konstitusi No. 14/PUU-XI/2013 yang mengabulkan sebagian permohonan uji materi (judicial review) Undang-Undang Nomor 42 Tahun 2008 Tentang Pemilihan Umum Presiden dan Wakil Presiden yang diajukan Effendi Gazali dkk aturan pemilu serentak ini muncul, keluarnya putusan MK ini merupakan salah satu terobosan hukum baru. Dimana dalam amar putusannya MK menyatakan: Pasal 3 Ayat (5), Pasal 12 Ayat (1) dan Ayat (2), Pasal 14 Ayat (2), dan Pasal 112 Undang-
Undang Nomor 42 Tahun 2008 tidak mempunyai kekuatan hukum mengikat (inkonstitusional). Dari rangkaian ketentuan yang dinyatakan kehilangan validitas konstitusional tersebut, MK menegaskan, pemilihan umum presiden dan wakil presiden harus dilaksanakan serentak dengan pemilihan umum anggota DPR, DPD, dan DPRD. Dengan putusan ini, ketentuan bahwa Pemilihan Umum Presiden dan Wakil Presiden (Pemilu Presiden) dilaksanakan setelahPemilihan Umum anggota DPR, DPD, dan DPRD (Pemilu Legislatif) adalah inkonstitusional, dalam diktum kedua dari amar putusan Mahkamah Konstitusi menegaskan bahwa putusan pemilu serentak akan diterapkan pada pemilu 2019.

Pelaksanaan pemilihan umum serentak dalam hal memilih anggota legislatif dan presiden, merupakan 
hal baru yang terjadi di Indonesia.

Pelaksanaan serentak ini di satu sisi memberikan harapan baru bagi Indonesia dalam menata pelasanaan pemilu yang efektif dan effisien, akan tetapi disisi lain pelaksanaan pemilu serentak ini mengundang tanda tanya di tengah-tengah masyarakat. Lebih lanjut lagi, sudah seberapa sering penyelenggara mensosialisasikan tentang pelaksanaan pemilu serentak ini kepada masyarakat dan bagaimana pemahaman masyarakat terkait dengan pelaksanaannya. Hal inilah yang menumbuhkan opini masyarakat terhadap pelaksanaan pemilu tahun 2019 ini.

$$
\text { Pemilihan umum (Pemilu) }
$$

menurut Haris (2006:10) merupakan salah satu bentuk pendidikan politik bagi rakyat, yang bersifat langsung, terbuka, massal, yang diharapkan bisa mencerdaskan pemahaman politik dan meningkatkan kesadaran masyarakat mengenai demokrasi. Sedangkan Hutington dalam Rizkiyansyah (2007:3) menyatakan bahwa sebuah Negara bisa disebut demokratis jika didalamnya terdapat mekanisme pemilihan umum yang dilaksanakan secara berkala atau periodik untuk melakukan sirkulasi elite".

Menurut Rahman (2007:194), pemilu merupakan cara dan sarana yang tersedia bagi rakyat untuk menentukan wakil-wakilnya yang akan duduk dalam Badan Perwakilan Rakyat guna menjalankan kedaulatan rakyat, maka dengan sendirinya terdapat berbagai sistem pemilihan umum.

Sementara itu, menurut Undang-Undang No. 7 Tahun 2017 tentang pemilihan umum Pasal 1 Poin 1 dijelaskan bahwa Pemilihan Umum yang selanjutnya disebut 
Pemilu adalah sarana kedaulatan

rakyat untuk memilih anggota

Dewan Perwakilan Rakyat, anggota

Dewan Perwakilan Daerah, Presiden

dan Wakil Presiden, dan untuk memilih anggota Dwan Perakilan

Rakyat Daerah, yang dilaksanakan

secara langsung, umm, bebas,

rahasia, jujur dan adil dalam Negara

Kesatuan Republik Indonesia

berdasarkan Pancasila dan Undang-

Undang Dasar Negara Republik

Indonesia Tahun 1945.

Penjelasan di atas menunjukan

bahwa pemilihan umum sebagai

sarana terwujudnya demokrasi.

Pemilihan umum adalah suatu alat

yang penggunaannya tidak boleh

mengakibatkan rusaknya sendi-sendi

demokrasi dan bahkan menimbulkan

hal-hal yang menderitakan rak yat,

tetapi harus tetap tegaknya Pancasila

dan dipertahankannya Undang-

Undang Dasar 1945.
Berdasarkan penjelasan para

ahli, dapat disimpulkan bahwa

melalui pemilu sistem demokrasi

dapat diwujudkan. Legitimasi

kekuasaan yang diperoleh

pemerintah menjadi kuat dan absah karena hal tersebut merupakan hasil

pikiran rakyat yang memiliki

kedaulatan. Selain sebagai

mekanisme demokrasi, pemilu ini

juga memiliki tujuan sebagai

pendidikan politik rakyat yang dapat

menumbuhkembangkan kesadaran

rakyat akan hak dan kewajiban

politiknya.

Melihat perubahan yang

terdapat dalam pemilu tahun 2019

ini, maka secara tidak langsung akan

memenuhi ruang pro kontra

ditengah-tengah masyarakat,

sehingga terbangun opini yang

berkembang dalam kehidupan

masyarakat Indonesia khusunya

masyarakat Kota Medan. Opini 
publik atau opini masyarakat adalah hasil penintegrasian pendapat berdasarkan diskusi yang dilakukan di dalam masyarakat demokrasi. Opini publik bukan seluruh pendapat individu-individu yang dikumpulkan (Abdurrachman, 1982:51).

Sementara itu Cangara (2011:127) menyatakan bahwa opini publik atau pendapat umum merupakan gabungan pendapat perseorangan mengenai suatu isu yang dapat mempengaruhi orang lain, serta memungkinkan seseorang dapat mempengaruhi pendapat-pendapat tersebut. Ini berarti pendapat umum hanya bisa terbentuk kalau menjadi bahan pembicaraan umum, atau jika banyak orang penting (elite) mengemukakan pendapat mereka tentang suatu isi sehingga bisa menimbulkan pro atau kontra di kalangan anggota masyarakat.
Opini masyarakat atau publik merupakan salah satu bentuk dari efek proses komunikasi politik. Dalam komunikasi politik, setiap partai atau kandidat politik berusaha melakukan proses penyampaian pesan yang bertujuan untuk mempengaruhi opini publik mengenai citra partainya. Salah satu cara dalam pembentukan opini publik ini adalah dengan penggunaan media massa. Media massa sering menjadi sumber informasi dan sebagai saluran komunikasi bagi para politisi. Media juga berperan dalam menyampaikan pemberitaanpemberitaan politik (political talks) yang dapat membentuk opini publik mengenai masalah politik dan atau aktor politik. (Hamad, 2004:9).

Opini merupakan tanggapan aktif terhadap rangsangan. Menurut Nimmo $(2000 ; 10)$, opini terdiri atas 
tiga komponen, yaitu kepercayaan,

nilai dan pengharapan.

1. Kepercayaan

Kepercayaan sangat berkaitan erat dengan aspek kognitif atau pikiran seseorang. Dalam hal ini kepercayaan mengacu pada sesuatu yang dapat diterima oleh khalayak.

2. Nilai

Nilai merupakan preferensi yang dimiliki oleh seseorang terhadap tujuan tertentu dan dengan cara tertentu dalam melakukan sesuatu. Nilai atau preferensi ini sangat berkaitan erat dengan aspek afektif atau perasaan seseorang. Nilai mengacu pada rasa suka atau tidak suka, penting atau tidak penting serta seberapa besar intensitasnya bagi orang tersebut.

3. Pengharapan
Pengharapan berkaitan erat dengan aspek konatif atau kecenderungan seseorang dalam bertindak di masa yang akan datang. Pengharapan sering kali juga dikatakan sebagai gerak hati, hasrat, kemauan ataupun dorongan.

Dalam proses pembentukan opini, terdapat beberapa faktor penting, antara lain latar belakang sejarah, faktor biologis, faktor sosial dan faktor psikologis. (Cangara, 2011;134-136).

Opini publik atau opini masyarakat adala asil penintegrasian pendapat berdasarkan diskusi yang dilakukan di dalam masyarakat demokrasi. Opini publik bukan seluruh pendapat individu-individu yang dikumpulkan (Abdurrachman, 1982:51). Sementara itu Cangara (2011:127) menyatakan bahwa opini publik atau pendapat umum 
merupakan gabungan pendapat luar ruang memberikan tingkat perseorangan mengenai suatu isu penerimaan yang baik bagi yang dapat mempengaruhi orang mahasiswa (Lubis, 2018:166). lain, serta memungkinkan seseorang Terkait dengan media dapat mempengaruhi pendapatsosialisasi, sudah semestinya media pendapat tersebut. Ini berarti sosialisasi yang dilakukan oleh pendapat umum hanya bisa terbentuk penyelenggara pemilu dilakukan kalau menjadi bahan pembicaraan secara massif dan menyeluruh. Hal umum, atau jika banyak orang penting (elite) mengemukakan pendapat mereka tentang suatu isi sehingga bisa menimbulkan pro atau kontra di kalangan anggota ini sebagaimana yang disampaikan oleh Anshori (2018:142) bahwa, media sosialisasi memiliki hubungan yang kuat dalam menentukan sikap dan pengetahuan pemilih.

masyarakat.

Berdasarkan hasil penelitian

\section{Metodologi Penelitian} tentang opini mahasiswa kota Medan Metode yang digunakan dalam terhadap iklan politik calon gubernur penelitian ini ialah metode dan wakil gubernur Sumatera Utara kuantitatif, dengan pendekatan tahun 2018 yang dilakukan oleh analisis korelasi dan regresi linear Lubis menemukan bahwa opini sederhana. Karena penelitian ini mahasiswa kota Medan sangat merupakan penelitian korelasional, beragam dalam melihat alat peraga maka penelitian ini bermaksud kampanye, dan pesan politik yang mendeteksi sejauh mana variasidisampaikan melalui iklan media variasi atau lebih faktor lain 
berdasarkan koefisien korelasinya.

Sedangkan analisis regresi linear

sederhana adalah untuk mengetahui

pengaruh variabel bebas (X)

terhadap variabel terikat (Y).

Lokasi penelitian pada penelitian ini adalah Kota Medan.

Populasi pada penelitian ini yang merupakan pemilih yang telah terdaftar dalam daftar pemilih tetap (DPT) yang berjumlah 1.621 .917 orang. Sedangkan sampel yang digunakan berdasarkan rumus Slovin dengan tingkat kesalahan sebesar 5\%, maka sampel dalam penelitian ini berjumlah 400 orang.

\section{Hasil dan Pembahasan}

Terkait dengan pengetahuan responden terhadap pelaksanaan pemilu sernetak tahun $2019,95,75 \%$ responden telah mengetahui bahwa pemilu tahun 2019 akan dilangsungkan bersamaaan antara pemilihan anggota legisltaif dengan pemilihan presiden, sedangkan $4,75 \%$ responde belum mengetahui bahwa pemilu 2019 akan dilaksanakan bersamaan antara memilih anggota legislatif dengan presiden.

Opini masyarakat terhadap pelaksanaan pemilu serentak tahun 2019, $77,50 \%$ responden setuju bahwa pelaksanaan pemilu dilaksanakan secara serentak antara memilih anggota legislative dengan presiden. $\quad 18,50 \%$ responden menyatakan biasa saja terhadap pelaksanaan pemilu serntak 2019 dan $4,00 \%$ responden menyatakan tidak setuju pelaksanaan pemilihan anggota legislatif dan pemilihan presiden dilaksanakan secara serentak.

Terkait dengan politik uang yang terjadi dalam pemilu, $73,50 \%$ responden menyatakan bahwa politik 
uang itu adalah sebuah kegiatan yang buruk. $6,00 \%$ responden menyatakan bahwa politik uang itu tidak buruk dan $20,50 \%$ responden menyatakan bahwa politik uang dalam pemilu merupakan sebuah kegiatan yang biasa saja.

Hasil penelitian terkait sikap responden terhadap pemberian dari calon yang turut serta dalam pemilu 2019, 47,25\% responden menyatakan akan menerima pemberiana dari calon peserta pemilu 2019. 42,25\% menyatakan tidak akan menerima pemberian dari calon peserta pemilu 2019. Dan terdapat $10,00 \%$ responden yang tidak dapat memberikan jawaban terkait pemberian kepada responden dari calon peserta pemilu 2019.

Media atau alat perga yang paling efektif menurut responden adalah dengan melakukan sosialisasi melalui televise, hal ini disampaikan oleh $22,75 \%$ responden. Sementara itu menggunakan media baju kaos dinyatakan oleh $20,75 \%$ responden. Selanjutnya $\quad 18,50 \%$ responden menyatakan spanduk merupakan media efktif dalam mensosialisasikan diri calon peserta pemilu 2019. $15,00 \%$ responden menyatakan kalender merupakan media yang efektif sebagai bagian dari media sosialisasi. Sedangkan $\quad 13,00 \%$ responden menyatakan bahwa baliho merupakan alat peraga kampanye yang efektif dalam mensosialisasikan calon peserta pemilu. Selebihnya responden menjawab alat peraga kampanye yang efektif dengan menggunakan poster sebesar 3,00\%, Koran atau surat kabar 1,25\%, sticker $0,25 \%$, Pin 0,50\%, melalui Radio $0,75 \%$ dan media lainnya sebesar $2,00 \% \quad$ serta $2,25 \%$ responden tidak memberikan jawaban. 
Sementara itu media sumber

referensi terpercaya bagi para

responden, $\quad 61,50 \%$ responden

menyatakan bahwa media TV

menjadi sumber terpercaya dalam

melihat perkembangan pemilu 2019.

$14,25 \%$ responden menytakan bahwa

infomasi yang disajikan melalui

media online, menjadi bagian dari

sumber referensi yang dapat

dipercaya. $10,00 \%$ responden

menyatakan bahwa sumber referensi

yang dapat dipercaya adalah

informasi yang disampaikan melalui

media sosial, selanjutnya $5,00 \%$

menyatakan melalui media Koran

atau surat kabar dan selebihnya

$1,00 \%$ menyatakan radio, $0,50 \%$

menyatakan majalah, $3,25 \%$

menyatakan grup pertemanan online,

dan media lainnya ada sekitar 4,50\%.

Sikap politik masyarakat Kota

Medan terhadap pilihan politiknya

terkait dengan calon anggota DPR RI berdasarkan latar belakang partai

politik, $27,75 \% \quad$ responden

menyatakan akan memilih Partai

Gerindra, dirutan kedua sekitar

$12,75 \%$ responden menyatakan akan

memilih PDIP, selanjutnya peringkat

ketiga di tempati oleh PAN dengan

tingkat keterpilihan dari responden

sekitar $12,25 \%$. Selanjutnya diikuti

Demokrat 6,50\%, PKS 5,25\%,

Golkar 4,25\%, PKB 2,50\%, PPP

2,25\%, Nasdem 2,00\%, Dengan

$14,75 \%$ responden belum

memberikan jawaban ataupu belum

tau dan $6,25 \%$ menyatakan tidak memilih.

Alasan responden memilih

calon anggota legislatif itu antara

lain adalah karena berasal dari

partai yang didukung sekitar 9,25\%,

$8,25 \%$ menyatakan karena orangnya

tegas, $7,75 \%$ menyatakan karena

orang nya perhatian pada rakyat,

$7,00 \%$ menyatakan karena 
berpengalaman, $\quad 6,75 \% \quad$ karena

calonnya pintar dan sekitar $6,50 \%$

menyatakan calon yang akan dipilih

karena orangnya jujur dan bersih dari

KKN. Adapun 22,00\% responden

tidak memberikan alasan atau karena

rahasia.

Untuk calon anggota Dewan

Perwakilan Daerah Republik

Indonesia (DPD RI) perwakilan

Sumatera Utara, berdasarkan hasil

penelitian yang telah dilakukan, 6

calon dengan perolehan suara

tertinggi adalah Abdul Hakim

Siagian dengan memperoleh $8,00 \%$

Suara, Muhammad Nuh 4,50\%, Ali

Yakub Matondang dan Parlindungan

Purba masing-masing 3,00\%, serta

Dedi Iskandar Batubara dan Faisal

Amri masing-masing $2,75 \%$ serta

$18,25 \%$ responden menyatakan tidak

memilih dan $47,50 \%$ responden

menyatakan tidak tahu atau belum

menjawab.
Sementara itu terkait sikap

politik pemilih terhadap pilihan

pasangan calon presiden dan wakil

presiden pada pemilu 2019, 59,00\%

responden menjatuhkan pilihan

kepada pasangan Prabowo dan

Sandiaga Uno, Sedangkan $22,50 \%$

responden memilih Jokowi dan

Ma'ruf Amin dengan 18,50\%

responden tidak menjawab.

Sementara itu berdasarkan latar

belakang tingkat pendidikan

responden dalam menentukan sikap

politik terhadap pasangan calon

presiden dan wakil presiden yang akan dipilih, ditemukan bahwa, responden tamatan SD sederajat, dari 39 orang responden, $38,46 \%$ nya memilih Jokowi-Ma'ruf Amin dan 17,95\% nya akan memilih PrabowoSandiaga Uno. Untuk responden tamatan SMP sederajat dari 42 orang, $83,33 \%$ responden akan memilih Jokowi-ma'ruf Amin dan 


$11,90 \%$ responden memilih latar belakang pendidikan SMP

Prabowo-Sandiaga Uno. Sedangkan kebawah, dengan hanya sekitar

untuk responden tamatan SMA 44,44\% yang memiliki latar belakang

sederajat yang berjumlah 230 orang, pendidikan SMA ke atas. Hal ini $14,78 \%$ responden akan memilih sangat berbanding terbalik dengan Jokowi-Ma'ruf Amin sedangkan para responden yang menetukan 67,83\% responden memilih pilihannya kepada PrabowoPrabowo-Sandiaga Uno. Dan untuk Sandiaga Uno. Dari 236 Orang responden yang tamatan pendidikan responden atau sekitar 59,00\% tinggi baik Diploma I sampai Sarjana responden, $5,08 \%$ responden yang berjumlah 89 orang, 76,40\% merupakan tamatan SMP sederajat responden akan memilih Prabowo- kebawah, sedangkan 94,92\% Sandiaga Uno dan $6,74 \%$ responden responden merupakan tamatan SMA akan memilih Jokowi-Ma'ruf Amin. sederajat keatas.

Melihat dari hasil tersebuut, dapat diutarakan bahwa dari latar Penutup belakang pendidikan, pemilih Berdasarkan hasil penelitian Jokowi-Ma'ruf amin merupakan tentang opini masyarakat Medan pemilih yang memiliki latar belakang terhadap pemilihan serentak pendidikan mayoritas menengah presdiden dan legislatif tahun, dapat kebawah, hal ini dapat dilihat dari 90 ditarik simpulan sebagaimana orang responden atau sekitar $22,50 \% \quad$ berikut:

responden, $55,56 \%$ diantaranya 1. Penelitian ini menemukan merupakan responden yang memiliki bahwa sekitar $95,25 \%$ responden 
telah mengetahui bahwa pemilu tahun 2019 akan dilaksanakan secara serentak anatara memilih presiden dan legislatif. Dan $77,50 \%$ responden menyatakan setuju terhadap pelaksanaan pemilihan presiden dan legislatif dilaksasnakan secara bersamaan.

2. Hasil penelitian juga melihat bahwa tanggapan responden terhadap money politics, $73,50 \%$ responden menyatakan bahwa money politics adalah merupakan perbuatan yang buruk, dengan $20,50 \%$ responden menyatakan bahwa hal tersebut baisa terjadi dan $6,00 \%$ responden myatakan bahwa money politics bukanlah sebuah hal yang buruk.

3. Terkait dengan preferensi politik pemilih, $20,75 \%$ responden menyatakan alat peraga kampanye yang paling efektif adalah dilakukan melalui iklan di televisi. Hal ini sebanding dengan jawaban dari $61,50 \%$ responden yang menyatakan bahwa siaran televise merupakan bagian dari media referensi yang dipercaya oleh para responden.

4. Selanjutnya terkait dengan sikap politik responden dalam menentukan pilihan, untuk calon Anggota DPR RI, 27,75\% responden akan memilih calon yang berasal dari partai Gerindra, $\quad 12,75 \%$ responden akan memilih calon yang berasal dari PDIP dan $12,25 \%$ responden akan memilih calon yang berasalan dari PAN. Untuk Calon Anggota DPD RI, terdapat 6 calon dengan perolehan suara tertinggi, yakni: Abdul Hakim Siagian 8,00\%, Muhammad Nuh 4,50\%, Ali Yakub Matondang dan 
Parlindungan Purba masing-

masing 3,00\%, serta Dedi

Iskandar Batubara dan Faisal

Amri masing-masing 2,75\%.

5. Untuk pilihan calon Presiden Republik Indonesia masa jabatan 2019-2024, 59,00\% responden menyatakan akan memilih Prabowo-Sandiaga Uno dan hanya $22,50 \%$ responden yang menyatakan akan memilih Jokowi-Ma'ruf Amin dengan $18,50 \%$ responden yang belum memberikan jawaban.

6. Sementara itu dari latar belakang pendidikan terakhir responden, pemilih Jokowi-Ma'ruf Amin mayoritas merupakan pemilih yang memiliki latar belakang pendidikan terakhir pada jenjang pendidikan SMP sederajat kebawah dengan angka sekitar $55,56 \%$. Sedang pemilih Prabowo-Sandiaga Uno

$$
\begin{aligned}
& \text { merupakan pemilih yang } \\
& \text { memiliki latar belakang } \\
& \text { pendidikan terakhir SMA } \\
& \text { sederajat keatas yang berkisar } \\
& 94,92 \% .
\end{aligned}
$$

\section{Daftar Pustaka}

Abdurrachman, Oemi. 1982. Dasardasar Public Relatons. Bandung: Alumni

Anshori, Akhyar. 2018. Pengaruh Iklan Politik Terhadap Persepsi Pemilih Kota Medan Tahun 2018. Jurnal Interaksi Vol. 2 No. 2, Hal: 132-144 FISIP UMSU. Medan.

Cangara, Hafid. 2011. Komunikasi Politik: Konsep, Teori dan Strategi. Jakarta: Raja Grafindo Persada.

Lubis, Faizal, Hamzah. 2018. Opini Mahasiswa Kota Medan Terhadap Iklan Politik Calon Gubernur dan Wakil Gubernur Sumatera Utara Tahun 2018. Jurnal Interaksi Vol. 2 No. 2, Hal: 157-166 FISIP UMSU. Medan.

Hamad, Ibnu. 2004. Konstruksi Realitas Politik Dalam Media Massa: Sebuah Studi Critical Discourse Analysis Terhadap Berita-berita Politik. Jakarta: Granit.

Haris, Syamsuddin. 2006. Membangun Format Baru Otonomi Daerah. Jakarta: Yayasan Obor Indonesia 
Nimmo, Dan. 2000. Komunikasi Politik Khalayak dan Efek. Bandung: Remaja Rosda Karya.

Rahman. A. 2007. Sistem Politik Indonesia. Yogjakarta: Graha Ilmu

Ridwan, 2008, Metode dan Teknik Menyusun Tesis. Bandung: Alfabeta.

Rizkiyansyah, F, K. 2007. Mengawali Pemilu Menatap Demokrasi. Bandung: IDEA Publishing.

Sugiyono. 2013. Statistika Untuk Penelitian. Bandung: Alfabeta

Undang-Undang Dasar 1945

Undang-Undang Nomor 7 Tahun 2017 Tentang Pemilihan Umum 